\title{
PERBEDAAN HITUNG JUMLAH TROMBOSIT MENGGUNAKAN DARAH VENA DAN DARAH KAPILER
}

\author{
Hieronymus Rayi Prasetya1), Maria Irena Dentri"1), Sistiyono²) \\ 1)Program Studi Analis Kesehatan STIKes Guna Bangsa Yogyakarta \\ 2) Program Studi Analis Kesehatan Poltekes Kemenkes Yogyakarta
}

\begin{abstract}
Background: Platelets play a role in hemostasis which is the body's mechanisms to prevent and stop the bleeding. Platelets participate in the effort to close the wound, so that the body does not experience a loss of blood and protected from foreign cells. Examination of the platelet count is very important in the diagnosis of diseases, one of which is the diagnosis of dengue hemorrhagic fever (DHF). Examination of blood counts, especially platelets in clinical laboratories causes blood samples in use are not always the venous blood but could use capillary blood. Capillary blood samples are used primarily in pediatric patients, because the venous blood sampling is difficult, patient loads, and also shorten the time when taking blood. The purpose of this study was to determine whether there is a difference in counting the number of platelets using samples of blood veins and capillaries.
\end{abstract}

Methods: Quantitative research with observational approach using a cross sectional study design in the 30 samples of student D3 Health Analyst STIKes To Nation Yogyakarta. Statistical methods in use are independent $\mathrm{T}$ test.

Results: The research subjects were 30 samples of student D3 Health Analyst STIKes To Nation Yogyakarta. The results of the examination of venous blood platelet count and blood capillaries have different average values are 247530 cells / ml of blood, for blood platelets veins and 184270 cells / $\mathrm{ml}$ of blood for capillary blood platelets. Spearman correlation analysis Obtained results of the examination of venous blood platelet count and blood capillaries normal distribution ( $p>0.05$ ). 0.129 venous blood platelet counts, while the number of blood platelets kapilernya 0.089 .

Conclusion: There is a significant difference from the results of counting the number of blood platelets using veins and capillaries, where the use of capillary blood samples showed that lower platelet counts.

Keywords: Platelets, Blood Veins, Blood Capillary

\section{PENDAHULUAN}

Pemeriksaan jumlah trombosit
bertujuan untuk mengetahui jumlah
trombosit permikro liter darah. Trombosit
berperan penting dalam proses
hemostasis yang merupakan mekanisme
tubuh untuk mencegah dan menghentikan
pendarahan. Trombosit ikut serta dalam
usaha menutup luka, sehingga tubuh tidak
mengalami kehilangan darah dan terhindar
dari sel asing. (Setiabudi, 2009).

Pemeriksaan jumlah trombosit sangat berperan penting dalam diagnosis penyakit, salah satunya adalah diagnosis demam berdarah dengue (DBD). Hingga kini diagnosis DBD masih berdasarkan patokan WHO tahun 1997 yang terdiri dari 4 kriteria klinis dan 2 kriteria laboratorik. Kriteria laboratorium yaitu trombositopenia $(<100.000 / \mathrm{mm} 3)$ dan hemokonsentrasi $(\mathrm{Ht}$ meningkat $>20 \%$ ). Pada pasien DBD terjadi trombositopenia akibat munculnya antibodi terhadap trombosit karena kompleks antigen-antibodi yang terbentuk. 
Hasil penelitian yang pernah dilakukan menunjukan bahwa semakin besar nilai hematokrit maka jumlah trombosit semakin menurun (Rasyada dkk, 2014) tetapi jumlah trombosit tidak berhubungan dengan kadar hemoglobin pada pasien DBD (Patandianan dkk, 2013). Jumlah trombosit juga dihubungkan dengan demam berdarah dengue tanpa syok dan syok (Heatubun dkk, 2013), selain itu jumlah trombosit juga dikaitkan dengan mortalitas pasien Infark Miokard Akut, dimana trombosit berperan penting dalam proses aterogenesis karena melepaskan matriks metaloproteinase yang terlibat dalam degradasi matriks plak aterosklerosis (Kurniawan dkk, 2014).

Pemeriksaan jumlah trombosit tidak boleh ditunda karena akan mempengaruhi hasil pemeriksaan jika dilakukan lebih dari 1 jam (Darmayanti dkk, 2014; Soebrata, 2011).

Pemeriksaan jumlah trombosit biasanya menggunakan darah vena karena disertai pemeriksaan laboratorium yang lainnya, tetapi berdasarkan hasil survei, meningkatnya permintaan pemeriksaan hitung sel darah terutama trombosit pada laboratorium klinik menyebabkan sampel darah yang di pakai tidak selalu darah vena tetapi bisa menggunakan darah kapiler. Sampel darah kapiler digunakan terutama pada pasien anak-anak, karena pengambilan darah vena sulit dilakukan, jumlah pasien yang banyak, dan juga mempersingkat waktu saat pengambilan darah. Oleh karena itu perlu dilakukan penelitian untuk mengetahui ada tidaknya perbedaan hitung jumlah trombosit menggunakan sampel darah vena dan darah kapiler.

\section{METODE PENELITIAN}

Jenis penelitian yang digunakan adalah penelitian kuantitatif dengan pendekatan observasional menggunakan desain penelitian crosssectional. Subjek dalam penelitian ini diambil dengan cara random sampling pada 30 sampel mahasiswa D3 Analis Kesehatan STIKes Guna Bangsa Yogyakarta. Hitung jumlah trombosit yang diperiksa menggunakan alat Hematology Analyzer. Analisis data dilakukan dengan menggunakan perhitungan secara statistik. Metode statistik yang di pakai adalah independent $\mathrm{T}$ test, untuk mengetahui ada tidaknya perbedaan hitung jumlah trombosit darah vena dan darah kapiler.

\section{HASIL PENELITIAN}

\begin{tabular}{|l|c|c|c|c|c|}
\hline \multirow{2}{*}{ No } & \multicolumn{2}{|c|}{ Jumlah Trombosit $\left(\times 10^{3}\right.$ sel $\left./ \mu \mathrm{l}\right)$} & \multirow{2}{*}{ No } & \multicolumn{2}{c|}{ Jumlah Trombosit $\left(\times 10^{3}\right.$ sel $\left./ \mu \mathrm{l}\right)$} \\
\cline { 2 - 3 } & Vena & Kapiler & & Vena & Kapiler \\
\hline 1 & 147 & 210 & 16 & 342 & 129 \\
\hline 2 & 224 & 229 & 17 & 251 & 31 \\
\hline 3 & 300 & 249 & 18 & 285 & 255 \\
\hline 4 & 255 & 260 & 19 & 328 & 69 \\
\hline 5 & 295 & 165 & 20 & 203 & 296 \\
\hline 6 & 244 & 165 & 21 & 277 & 137 \\
\hline 7 & 285 & 172 & 22 & 294 & 281 \\
\hline 8 & 344 & 255 & 23 & 234 & 219 \\
\hline 9 & 260 & 184 & 24 & 282 & 285 \\
\hline 10 & 206 & 183 & 25 & 59 & 155 \\
\hline 11 & 289 & 169 & 26 & 84 & 200 \\
\hline 12 & 211 & 139 & 27 & 225 & 157 \\
\hline 13 & 262 & 111 & 28 & 184 & 297 \\
\hline 14 & 260 & 152 & 29 & 260 & 208 \\
\hline 15 & 237 & 160 & 30 & 299 & 206 \\
\hline
\end{tabular}




\begin{tabular}{|l|l|l|l|l|l|}
\hline Keterangan & $\mathrm{N}$ & Ratarata & $\begin{array}{l}\text { Nilai } \\
\text { maksimum }\end{array}$ & $\begin{array}{l}\text { Nilai } \\
\text { minimum }\end{array}$ & $\begin{array}{l}\text { Std. } \\
\text { Deviasi }\end{array}$ \\
\hline darahvena & 30 & 247.530 & 344 & 59 & 65.571 \\
\hline darahkapiler & 30 & 184.270 & 297 & 31 & 67.346 \\
\hline
\end{tabular}

Dari tabel tersebut dapat dilihat bahwa hasil pemeriksaan jumlah trombosit darah vena dan darah kapiler memiliki nilai rata rata yang berbeda yaitu $247.530 \mathrm{sel} / \mu \mathrm{l}$ darah, untuk trombosit darah vena dan $184.270 \mathrm{sel} / \mu \mathrm{l}$ darah untuk trombosit darah kapiler.

\begin{tabular}{|c|c|c|c|}
\hline 1. & Normalitas data & Statistik & Hasil \\
\hline & darah vena & 0,129 & Distribusi normal \\
\hline & darah kapiler & 0,089 & Distribusi normal \\
\hline 2. & Uji beda "T-test" & 0,001 & Terdapat perbedaan yang bermakna \\
\hline
\end{tabular}

Didapatkan hasil pemeriksaan jumlah trombosit darah vena dan darah kapiler berdistribusi normal $(p>0.05)$. Jumlah trombosit darah vena 0,129 , sedangkan jumlah trombosit darah kapilernya 0,089. Hasil uji beda pada pemeriksaan jumlah trombosit darah vena dan darah kapiler dapat diketahui bahwa diperoleh sig(2tailent) sebesar 0.001 yang lebih kecil dari 0.05 yang berarti bahwa $\mathrm{Ha}$ diterima dan Ho ditolak (Ha diterima jika $p$ value $>0.05$ ), berarti terdapat perbedaan yang bermakna pada hasil pemeriksaan jumlah trombosit menggunakan darah vena dan darah kapiler.

\section{PEMBAHASAN}

Hitung jumlah trombosit adalah salah satu pemeriksaan yang sering dilakukan di Rumah Sakit maupun di Puskesmas, yang bertujuan untuk mengetahui jumlah trombosit per mikro liter darah. Fungsi utama trombosit adalah pembentukan sumbatan mekanis selama respon hemostatik normal terhadap luka vaskular. Trombosit berfungsi penting pada usaha tubuh untuk mempertahankan jaringan bila terjadi luka. Trombosit ikut serta dalam usaha menutup luka, sehingga tubuh tidak mengalami kehilangan darah dan terlindung dari penyusupan benda atau sel asing.

Penelitian ini menggunakan darah vena dan darah kapiler. Darah vena dan darah kapiler yang dipakai yaitu spesimen darah yang baru (tanpa penundaan pemeriksaan untuk menghidari trombosit adhesi dan agregasi yang mengganggu alat hematology analyzer dalam menghitung trombosit) dan menggunakan antikoagulan K2EDTA (Ethylene Diaminete Tetra Acetat) yang sudah tersedia dalam tabung vacutainer dengan tujuan menjaga agar darah tetap cair. Penggunaan EDTA dapat mempengaruhi hasil pemeriksaan trombosit, dimana EDTA konvensional (Na2EDTA) menyebabkan perhitungan jumlah trombosit lebih rendah (Wijaya, 2006).

Sampel darah diperiksa menggunakan alat hematology analyzer (metode otomatis), karena mempunyai keuntungan antara lain penghematan waktu, ketepatan dan ketelitian yang tinggi, dan beban kerja lebih ringan. Sebelum dilakukan pemeriksaan dilakukan validasi alat hematology analyzer agar alat dapat bekerja optimal. Uji validasi dilakukan menggunakan bahan kontrol.

Jumlah trombosit darah yang diambil dari pembuluh darah vena lebih banyak daripada jumlah trombosit darah yang diambil di ujung jari (pembuluh darah kapiler). Setelah dilakukan pengolahan data menggunakan uji beda Independent Sample T-Test dapat dikatakan bahwa pemeriksaan jumlah trombosit menggunakan darah vena dan darah kapiler terdapat perbedaan yang bermakna dimana hasil 
menunjukan bahwa jumlah trombosit darah vena didapatkan rata-rata 247.53 $\mathrm{sel} / \mu \mathrm{l}$ darah sedangkan jumlah trombosit darah kapiler didapatkan rata-rata 184.27 $\mathrm{sel} / \mu \mathrm{l}$ darah, hal ini dipengaruhi oleh karena darah kapiler yang diambil pada ujung jari berukuran kecil, berbeda dengan ukuran pembuluh darah vena yang berukuran besar, sehingga pada saat pengambilan sampel darah kapiler, jari yang di ambil darahnya diperlakukan dengan cara di pijat hingga darahnya keluar, pemijatan tersebut menyebabkan cairan yang ada didalam jaringan juga ikut keluar bersama dengan darah sehingga menyebabkan darah kapiler menjadi lebih encer dan trombosit akan membeku (adhesi dan agregasi) karena terdapat cairan jaringan. Pemeriksaan Hitung jumlah trombosit disarankan menggunakan darah vena agar tidak terjadi kesalahan karena, hitung jumlah trombosit sangat penting untuk menunjang diagnosa gangguan perdarahan. Hal ini didukung oleh penelitian sebelumnya dimana terdapat perbedaan bermakna pengukuran kadar hemoglobin menggunakan darah vena dan kapiler (Mardhiyanto, 2010) tetapi perbedaan tidak bermakna pada pengukuran kadar glukosa menggunakan darah vena dan kapiler (Yap dkk, 2013).

\section{SIMPULAN}

Terdapat perbedaan yang bermakna dari hasil pemeriksaan hitung jumlah trombosit menggunakan darah vena dan darah kapiler, dimana penggunaan sampel darah kapiler menunjukan jumlah trombosit yang lebih rendah.

\section{DAFTAR PUSTAKA}

Darmayanti, N. W., Oka, T. G., Santoso, A. P. R., 2014. Perbedaan Hasil Pemeriksaan Jumlah Trombosit Pada Sampel Darah Yang Langsung Diperiksa Dengan Yang Ditunda Selama 1 Jam, 2 Jam, Dan 3 Jam Menggunakan Alat Hematology
Analyzer Bc 2600. Klinika Laboratory

Desember; (1) : 2 : 107-112

Gandasoebrata, R. 2010. Penuntun laboratorium Klinik, Edisi 16.7-36, Dian Rakyat. Jakarta

Heatubun, C., Umboh, A., Mongan, A. E., Manoppo, F. 2013. Perbandingan Jumlah Trombosit Pada Demam Berdarah Dengue Tanpa Syok Dan Syok Di Rsup Prof. Dr. R. D. Kandou Manado. Jurnal e-Biomedik, (1): (2) : 863-867

Kurniawan, L.B., Bahrun, U., Darmawaty, E. R., Arif, M. 2014. Analisis Kaitan Jumlah Trombosit Dengan Mortalitas Pasien Infark Miokard Akut Selama Perawatan. CDK-220; (41) : 9

Mardhiyanto, F. 2010. Perbedaan Hasil Pemeriksaan Kadar Hemoglobin Metode Cyanmeth Antara Darah Kapiler Dan Vena Pada Mahasiswa Analis Kesehatan Universitas Muhammadiyah Semarang.

Patandianan, R., Mantik, M. F., Manoppo, F., Mongan, A. E. 2013.Hubungan Kadar Hemoglobin Dengan Jumlah Trombosit Pada Pasien Demam Berdarah Dengue. Jurnal $e$ Biomedik; (1): 2 : 868-872

Rasyada, A., Nasrul, E., Edward, Z. 2014. Hubungan Nilai Hematokrit Terhadap Jumlah Trombosit pada Penderita Demam Berdarah Dengue.Jurnal Kesehatan Andalas; (3) : 343-347

Setiabudi, Rahajuningsih D. 2009. Hemostasis dan Trombosis. Jakarta : FKUI. Halaman 23-32.

Wijaya, C. K. 2006. Perbedaan Jumlah Trombosit Cara Manual Pada Pemberian Antikoagulan EDTA Konvensional (Pipet Mikro) Dengan EDTA Vacutainer. Skripsi. Fakultas Kedokteran UNDIP.

Yap, A., Sugiarto, C., Sadeli, L. 2013.Perbandingan Kadar Glukosa Darah Kapiler Dengan Kadar Glukosa Darah Vena Menggunakan Glukometer Pada Penderita Diabetes Melitus Repository. Maranatha.Edu/1010143 